\title{
Antiproliferation of Hepatoma Cell and Progression of Cell Cycle as Affected by Isoflavone Extracts from Soybean Cake
}

\author{
Tsai-Hua Kao, Rwei-Fen S. Huang and Bing-Huei Chen* \\ Department of Nutrition and Food Sciences, Fu Jen University, Taipei 242, Taiwan \\ * Author to whom correspondence should be addressed; E-mail: 002622@mail.fju.edu.tw; \\ Phone: 886-2-29053626; Fax: 886-2-29021215
}

Received: 10 September 2007; in revised form: 30 October 2007 / Accepted: 5 November 2007 / Published: 21 November 2007

\begin{abstract}
The objectives of this study were to isolate various isoflavone fractions and extracts from soybean cake by preparative column chromatography and compare them with isoflavone standards with regards to inhibition of HepG2 cancer cell proliferation. Four fractions, including malonylglucoside, glucoside, acetylglucoside and aglycone, and two isoflavone extracts, ISO-1 and ISO-2, were collected for evaluation. MTT test results showed that most treatments were slightly protective against HepG2 cell growth at a low dose of isoflavone ( 5 and $10 \mu \mathrm{g} / \mathrm{mL}$ ). However, at elevated concentration of isoflavone (20-50 $\mu \mathrm{g} / \mathrm{mL})$, both aglycone and acetylglucoside fractions as well as a mixture of isoflavone standards were the most effective in inhibition, demonstrating a possible synergistic phenomenon. Genistein showed a better retardation effect than daidzein. For cell cycle analysis, both aglycone and acetylglucoside fractions and a mixture of isoflavone standards exhibited a high G2/M ratio, correlating well with the result of MTT test. The presence of some other functional components in soybean cake like saponins and phenolic compounds may also play a vital role in inhibiting HepG2 cell growth.
\end{abstract}

Keywords: Soybean cake; isoflavone extracts; MTT test; cell cycle analysis.

\section{Introduction}

According to a report by the American Institute for Cancer Research [1], Western people are more likely to be exposed to cancer risks such as breast, colon and prostate cancers than Oriental people, which may be associated with lifestyle and diet habits. Adlercreutz [2] further pointed out that Oriental 
men consumed more vegetable foods, while Western men consumed more animal products rich in protein and fat, which may affect hormone synthesis and metabolism leading to difference in incidence of cancers. Epidemiological studies have demonstrated that the intake of more vegetables and fruits in diets can reduce cancer risk, which can be attributed to the presence of functional components like flavonoids $[3,4]$.

Isoflavones, a major class of flavonoids, are a class of phytoestrogen mainly present in soybean foods and has been shown to be present at a high concentration in blood and urine of men in regions with a low occurrence of cancer risk [5]. Isoflavones have been shown to be effective in preventing breast cancer through binding with estrogen receptor and sex hormone binding globulin for reduction of estrogen activity [6]. In addition, isoflavones may inhibit cancer cell proliferation and phosphorylation by retarding activities of tyrosine kinase and DNA topoisomerase, as well as induce cancer cell differentiation and apoptosis through anti-angiogenesis [6].

Over the past decade numerous reports have been published regarding cancer inhibition by isoflavones, but most studies have focused on the aglycone isoflavones daidzein and genistein. It has been well documented the inhibition efficiency of growth of various types of cancer cells can be dependent upon isoflavone concentration. Peterson and Barnes [7] reported that both daidzein and genistein may suppress growth of breast cancer cell lines MCF-7 and MDA-468. In a similar study Scholar and Toews [8] found that a 50\% inhibition of breast cancer cell occurred for 1-2 $\mu \mathrm{M}$ genistein, however, a complete retardation was attained at $100 \mu \mathrm{M}$. Likewise, the genistein dose to achieve a $50 \%$ inhibition of breast cancer cell line $\mathrm{MCF}-10 \mathrm{~F}$ was $19-22 \mu \mathrm{M}\left(\mathrm{IC}_{50}\right)$, whereas a $90 \%$ retardation was noted at $45 \mu \mathrm{M}$ [9]. It was also observed that breast cancer cell failed to proliferate after genistein treatment because the cell cycle was terminated at G2/M phase, but in a study dealing with inhibition of prostate cancer cell lines PC3 and LNCaP as affected by genistein alone and a mixture of genistein and $\beta$-lapachone, Kumi-Diaka [10] revealed that both provided an inhibitory effect and increased cell apoptosis rate following a rise in genistein concentration, but a level of $70 \mu \mathrm{M}$ was necessary to attain a similar effect. In a later study Chang et al. [11] reported that liver cancer cell HepG2 can be terminated at $\mathrm{G} 2 / \mathrm{M}$ phase by genistein because of activation of ataxia-telangiectasia-mutated (ATM) gene through decrease of cdc 2 activity and enhancement of checkpoint kinase (chk 2) activity. Likewise, the dose in retarding 50\% proliferation of Chinese hamster lung fibroblast cell line (V 79) by genistein was $75 \mu \mathrm{M}(20.3 \mu \mathrm{g} / \mathrm{mL})$ [12]. Oki et al. [13] also reported a complete inhibition (100\%) of human prostate cancer cell line (DU 145) in the presence of 50,75 or $100 \mu \mathrm{M}$ of genistein.

All the studies mentioned above clearly indicated that isoflavones like daidzein and genistein were efficient in inhibiting cancer cell growth. However, there is still a paucity of data regarding the tumor cell growth as affected by isoflavone extracts or a mixture of isoflavone standards. Soybean cake, a defatted soybean meal product obtained during processing of soybean oil, has been shown to be a rich source of isoflavones and other functional components such as saponin and phenolic compounds [14]. The objectives of this study were to isolate four fractions of isoflavones, malonylglucoside, acetylglucoside, glucoside and aglycone, as well as two isoflavone extracts from soybean cake by preparative column chromatography and compared with various isoflavone standards in terms of antiproliferation of HepG2 tumor cell and progression of cell cycle. 


\section{Results and Discussion}

The concentration of isoflavone standards and extracts used in this experiment were based on those reported in the literature and the results of our preliminary studies. Table 1 shows the contents of various isoflavones in each fraction and standard solutions [14].

\subsection{MTT test}

Figure 1 shows the effect of various concentrations of isoflavone fractions and extracts as well as standards on relative cell survival percentage of HepG2 cell after $72 \mathrm{~h}$. The aglycone fraction showed a $65.9 \%$ cell survival at a low dose of $5 \mu \mathrm{g} / \mathrm{mL}$, which was substantially lower than the other four isoflavone fractions and two extracts (ISO-1 and ISO-2) as well as standards at the same dose, with the survival rate ranging from $83.6-92.8 \%$. This outcome indicated that a low concentration of $5 \mu \mathrm{g} / \mathrm{mL}$ is inadequate to suppress HepG2 cell growth. However, with concentration at $10 \mu \mathrm{g} / \mathrm{mL}$, a slight improvement in HepG2 cell growth inhibition was observed for all the isoflavone fractions and extracts, especially for the aglycone fraction, as the cell survival rate decreased to $49.9 \%$. Following a rise in both concentrations of isoflavone fractions and extracts, the aglycone fraction possessed the most pronounced inhibition (71.3\%) at $20 \mu \mathrm{g} / \mathrm{mL}$, followed by acetylglucoside (45.2\%), ISO-2 (29.0\%), malonylglucoside (22.1\%), glucoside (16.3\%) and ISO-1 (13.9\%).

Table 1. Contents $(\mu \mathrm{g} / \mathrm{mL})$ of isoflavones in each fraction and standard solutions.

\begin{tabular}{|c|c|c|c|c|c|c|c|c|c|c|c|c|c|}
\hline \multirow{2}{*}{ Isoflavones } & \multicolumn{6}{|c|}{ Isoflavone fractions } & \multicolumn{7}{|c|}{ Isoflavone standard solutions } \\
\hline & $\mathbf{M}$ & $\mathbf{G}$ & Ac & Ag & ISO-1 & ISO-2 & Mgin & Gin & Agin & Gein & Dein & 2 std & 4 std \\
\hline Malonyldaidzin & $48.8 \pm 0.3$ & - & - & - & $22.9 \pm 0.0$ & $12.0 \pm 0.0$ & - & - & - & - & - & - & - \\
\hline Malonylglycitin & $16.0 \pm 0.2$ & - & - & - & $8.1 \pm 0.2$ & $4.0 \pm 0.0$ & - & - & - & - & - & - & - \\
\hline Malonylgenistin & $35.1 \pm 1.2$ & - & - & - & $17.0 \pm 0.1$ & $8.8 \pm 0.1$ & 100.0 & - & - & - & - & - & 100.0 \\
\hline Daidzin & - & $25.3 \pm 0.1$ & - & - & $9.1 \pm 0.1$ & $6.3 \pm 0.1$ & - & - & - & - & - & - & - \\
\hline Glycitin & - & $29.2 \pm 0.2$ & - & - & $9.0 \pm 0.1$ & $7.3 \pm 0.1$ & - & - & - & - & - & - & - \\
\hline Genistin & - & $45.9 \pm 1.6$ & - & - & $26.3 \pm 0.1$ & $11.5 \pm 0.2$ & - & 100.0 & - & - & - & - & 100.0 \\
\hline Acetyldaidzin & - & - & $19.7 \pm 0.9$ & - & $1.3 \pm 0.0$ & $4.9 \pm 0.1$ & - & - & - & - & - & - & - \\
\hline Acetylglycitin & - & - & $12.8 \pm 0.7$ & - & $1.0 \pm 0.0$ & $3.2 \pm 0.2$ & - & - & - & - & - & - & - \\
\hline Acetylgenistin & - & - & $69.0 \pm 1.6$ & - & $2.5 \pm 0.0$ & $17.3 \pm 0.3$ & - & - & 100.0 & - & - & & 100.0 \\
\hline Daidzein & - & - & - & $47.3 \pm 0.5$ & $1.4 \pm 0.1$ & $11.9 \pm 0.1$ & - & - & - & - & 100.0 & 100.0 & - \\
\hline Glycitein & - & - & - & $16.3 \pm 0.2$ & $0.6 \pm 0.0$ & $4.1 \pm 0.0$ & - & - & - & - & - & - & - \\
\hline Genistein & - & - & - & $36.4 \pm 0.1$ & $1.0 \pm 0.0$ & $9.2 \pm 0.1$ & - & - & - & 100.0 & - & 100.0 & 100.0 \\
\hline Total & $99.9 \pm 1.7$ & $100.4 \pm 0.8$ & $101.5 \pm 2.1$ & $100.0 \pm 0.6$ & $100.2 \pm 0.0$ & $100.5 \pm 0.2$ & 100.0 & 100.0 & 100.0 & 100.0 & 100.0 & 200.0 & 400.0 \\
\hline
\end{tabular}

M: malonylglucoside fraction; G: glucoside fraction; Ac: acetylglucoside fraction; Ag: aglycone fraction; ISO-1: soybean cake extract containing 12 isoflavones; ISO-2: a mixture of 4 fractions of isoflavone extracts. Mgin: malonylgenistin; Gin: genistin; Agin: acetylgenistin; Gein: genistein; Dein: daidzein; 2 std: a mixture of daidzein and genistein standards; 4 std: a mixture of malonylgenistin, genistin, acetylgenistin and genistein standards. Based on a previous report by Kao and Chen [14]. 
Figure 1. Inhibition effect of isoflavones on Hep G2 cell growth as determined by MTT. (A) $5 \mu \mathrm{g} / \mathrm{mL}$ (B) $10 \mu \mathrm{g} / \mathrm{mL}$ (C) $20 \mu \mathrm{g} / \mathrm{mL}$ (D) $30 \mu \mathrm{g} / \mathrm{mL}$ (E) $40 \mu \mathrm{g} / \mathrm{mL}$ (F) $50 \mu \mathrm{g} / \mathrm{mL}$. M: malonylglucoside fraction; G: glucoside fraction; Ac: acetylglucoside fraction; Ag: aglycone fraction; ISO-1: soybean cake extract containing 12 isoflavones; ISO-2: a combination of four groups of isoflavone fractions; Mgin: malonylgenistin; Gin: genistin; Agin: acetylgenistin; Gein: genistein; Dein: daidzein; 2 std: a combination of daidzein and genistein; 4 std: a combination of malonylgenistin, genistin, acetylgenistin and genistein.
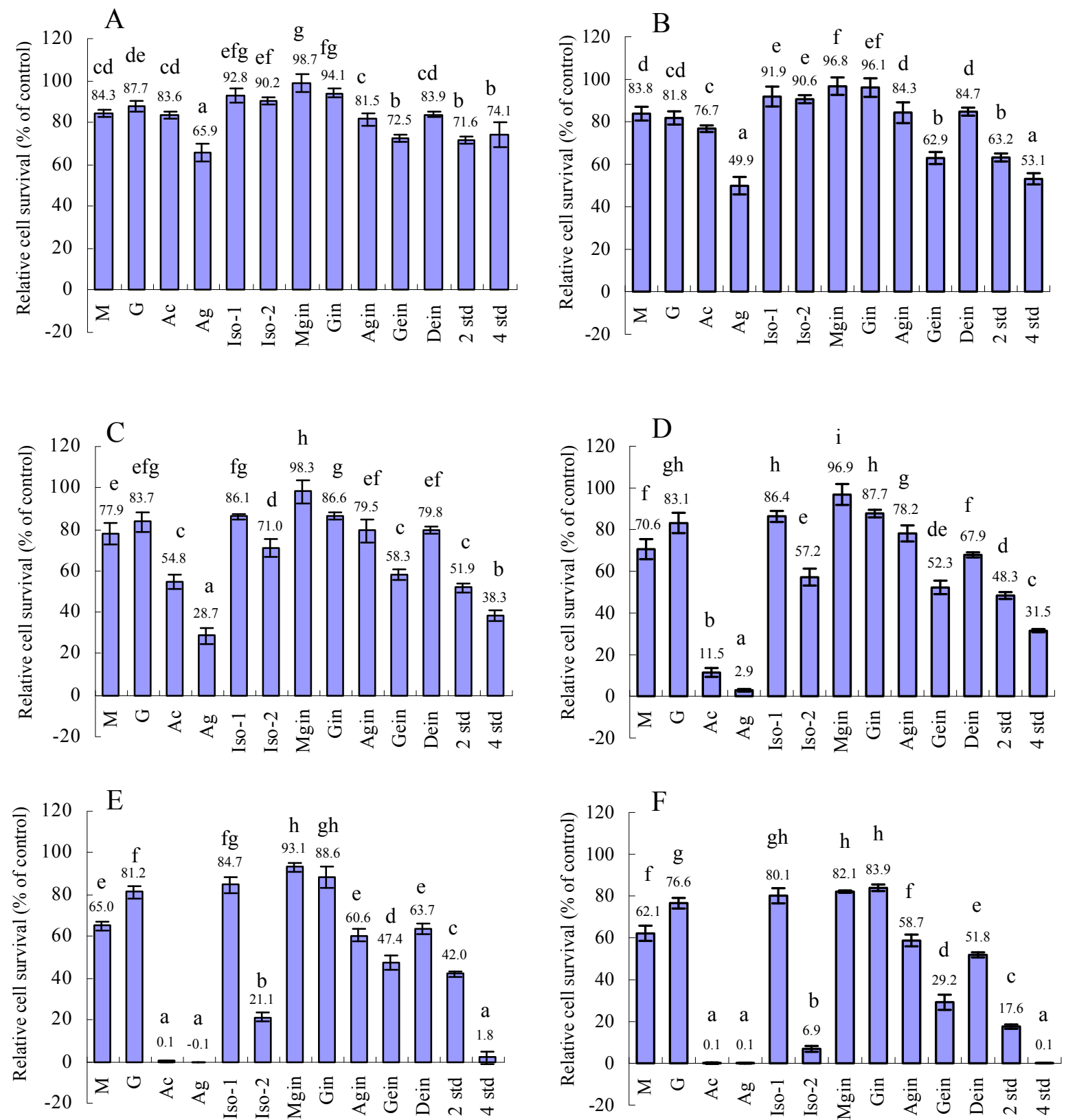

Likewise, a distinct suppression occurred for both aglycone and acetylglucoside fractions at 30 $\mu \mathrm{g} / \mathrm{mL}$ (97.1 and $88.5 \%$, respectively), whereas a complete inhibition (100\%) was attained at 40 or 50 $\mu \mathrm{g} / \mathrm{mL}$. For ISO-2 at 40 and $50 \mu \mathrm{g} / \mathrm{mL}$, a high inhibition of 78.9 and $93.1 \%$ was also shown, respectively. Like isoflavone fractions and extracts at low dose $(5 \mu \mathrm{g} / \mathrm{mL})$, all isoflavone standards 
only provided a slightly protective effect against tumor cell growth. Nevertheless, a mixture of isoflavone standards ( 2 std and $4 \mathrm{std}$ ) did show a better inhibition than single isoflavone standard, implying a synergistic effect may occur. Of the five isoflavone standards, genistein was the most effective against cancer cell proliferation, which may be due to the presence of one more hydroxyl group. Comparatively, a marked inhibition was achieved for 2 std and 4 std at $50 \mu \mathrm{g} / \mathrm{mL}$, which amounted to 82.4 and $99.9 \%$, respectively.

In the MTT test, all the treatments at low dose (5 and $10 \mu \mathrm{g} / \mathrm{mL})$ showed poor inhibition of HepG2 cell growth, with the exception of acetylglucoside fraction and a mixture of isoflavone standards as well as genistein. However, at elevated concentrations $(20-50 \mu \mathrm{g} / \mathrm{mL})$, a marked inhibition occurred for both aglycone and acetylglucoside fractions compared to isoflavone standards, which may be due to the presence of some other functional components like saponins, flavonoids and phenolic compounds [14]. In a previous study Kao and Chen [14] reported that both aglycone and acetylglucoside fractions exhibited higher antioxidant activity than isoflavone standards, which may be also responsible for retardation of HepG2 cell growth. It is worth pointing out that a combination of four isoflavone fractions (ISO-2) did possess a high inhibition at a level of 40 or $50 \mu \mathrm{g} / \mathrm{mL}$.

For isoflavone standards used alone, genistein provided the most distinct inhibition, followed by daidzein and acetylgenistin, while both malonylgenistin and genistin showed a low suppression effect. From the structural point of view, genistein contains one more hydroxyl group than daidzein and should exhibit a higher antioxidant activity, which may lead to a greater inhibition of HepG2 tumor cell growth. Similar outcome was reported by several other authors. Hewitt and Singletary [15] studied the effect of various levels of soybean extracts and genistein as well as daidzein in feed on breast cancer cell line in BALB/c rats, and found the most efficient inhibition (90\%) to be $0.6 \%$ soybean extract, with daidzein being less effective in decreasing tumor weight than genistein. A report by Constantinou et al. [16] also revealed soybean extract containing $750 \mathrm{ppm}$ genistein to be more effective in inhibiting cancer cell growth than isoflavone standards, probably caused by the combination effect of genistein and some other functional components like saponins and phenolic compounds [14]. Di Virgilio et al. [12] compared the effect of different levels of genistein, daidzein and equol on inhibition of tumor cell V79 and reported the retardation concentration of genistein to be 5-25 $\mu \mathrm{M}$. However, a level of 25 or $100 \mu \mathrm{M}$ was necessary for daidzein to achieve the same inhibition effect. Sakamoto [17] studied the effect of thearubigin and genistein on inhibition of human prostate cancer cell line (PC-3) and found the former to be ineffective at a dose of 0.5, 1.0, 2.5, 5.0, 10.0 and $20.0 \mu \mathrm{g} / \mathrm{mL}$. But, for genistein, a level of $5 \mu \mathrm{g} / \mathrm{mL}$ was adequate for inhibition, and a synergistic effect did occur for thearubigin and genistein when combined. In a similar study dealing with inhibition of prostate cancer cell line PC3 and LNCaP as affected by $\beta$-lapachone (topoisomerase inhibitor) and genistein, Kumi-Diaka [10] demonstrated that a combination of both showed a greater inhibition effect than when used alone. All these results strongly suggested that a mixture of isoflavone standards should perform better than single isoflavone standard in tumor cell antiproliferation.

According to a report by Wei et al. [18,19], genistein could inhibit tumor promoter-induced hydrogen peroxide formation and UV-induced 8-hydroxy-2'-deoxyguanosine in mice skin. The antioxidant activity of isoflavones may lead to diminishing peritoneal tumor recurrence, inhibiting cancer cell metastasis and lowering occurrence of prostatic intraepithelial neoplasia [20-22]. In our previous study we also demonstrated that with concentration at $100 \mu \mathrm{g} / \mathrm{mL}$, both isoflavone fractions 
and standards were effective in scavenging DPPH free radicals, chelating ferrous ion and inhibiting conjugated diene formation as well as liposome oxidation [14]. It was also observed that the isoflavone fractions exhibited a larger antioxidant activity than isoflavone standards, especially for the aglycone and acetylglucoside, which may be due to the presence of some other functional components such as saponins and phenolic compounds [14]. This phenomenon correlated well with the result of MTT test, implying the antioxidant activity of isoflavone fractions should play a vital role in retarding HepG2 cell proliferation. Nonetheless, it is worth pointing out that for antioxidant activity test, acetylgenistin was less efficient than genistein or daidzein, but for MTT test, the difference between acetylgenistin and daidzein or genistein was minor. This outcome suggested that the presence of acetyl group in acetylgenistin may be important in inhibiting HepG2 cell growth. A similar phenomenon was reported by Popiolkiewicz et al. [23], who studied the effect of genistein and its glucoside on toxicity of tumor cell Balb/c 3T3 and found that genistein glucoside containing an acetyl moiety possessed a higher biological activity. Also, the more the acetyl group in the isoflavone structure, the better the antiproliferation of cancer cells. It can be postulated that the acetyl group-containing isoflavone glucosides may be more selective to motality of tumor cells.

Table 2. The $\mathrm{IC}_{50}$ value of isoflavone fractions and extracts from soybean cake as well as isoflavone standards.

\begin{tabular}{|c|c|c|c|c|c|c|c|c|c|c|c|c|c|}
\hline Isoflavone & $\mathbf{M}$ & G & Ac & Ag & Iso-1 & Iso-2 & Mgin & Gin & Agin & Gein & Dein & 2 std & $4 \mathrm{std}$ \\
\hline $\mathrm{IC}_{50}(\mu \mathrm{g} / \mathrm{mL})$ & 69.4 & 186.8 & 19.9 & 8.8 & 163.7 & 28.7 & 171.3 & 196.8 & 65.3 & 29.9 & 53.4 & 23.8 & 15.1 \\
\hline
\end{tabular}

M: malonylglucoside fraction; G: glucoside fraction; Ac: acetylglucoside fraction; Ag: aglycone fraction; ISO-1: soybean cake extract containing 12 isoflavones; ISO-2: a combination of four groups of isoflavone fractions; Mgin: malonylgenistin; Gin: genistin; Agin: acetylgenistin; Gein: genistein; Dein: daidzein; 2 std: a combination of daidzein and genistein; 4 std: a combination of malonylgenistin, genistin, acetylgenistin and genistein.

Table 2 shows the $\mathrm{IC}_{50}$ value of isoflavone fractions and extracts as well as standards. The lowest $\mathrm{IC}_{50}$ value was shown for the aglycone fraction, implying a low concentration $(8.8 \mu \mathrm{g} / \mathrm{mL})$ is adequate to inhibit 50\% HepG2 cell growth. The mixture of four isoflavone standards (4 std) also showed a low IC $_{50}$ value $(15.1 \mu \mathrm{g} / \mathrm{mL})$, followed by acetylglucoside fraction $(19.9 \mu \mathrm{g} / \mathrm{mL}), 2 \mathrm{std}(23.8 \mu \mathrm{g} / \mathrm{mL})$, ISO$2(28.7 \mu \mathrm{g} / \mathrm{mL})$, genistein $(29.9 \mu \mathrm{g} / \mathrm{mL})$, daidzein $(53.4 \mu \mathrm{g} / \mathrm{mL})$, acetylgenistin $(65.3 \mu \mathrm{g} / \mathrm{mL})$, malonylglucoside $(69.4 \mu \mathrm{g} / \mathrm{mL})$, ISO-1 $(163.7 \mu \mathrm{g} / \mathrm{mL})$, malonylgenistin $(171.3 \mu \mathrm{g} / \mathrm{mL})$, glucoside $(186.8 \mu \mathrm{g} / \mathrm{mL})$ and genistin $(196.8 \mu \mathrm{g} / \mathrm{mL})$. As there is no information available regarding the $\mathrm{IC}_{50}$ of HepG2 cell as affected by isoflavone fractions and extracts, our study demonstrated that isoflavone and its glucoside derivatives may possess different inhibition effect on tumor cell growth, with a mixture of isoflavone standards being more effective than single isoflavone standard. A similar outcome was observed by several other authors. Frey et al. [9] reported that a level of $45 \mu \mathrm{M}$ (12 $\mu \mathrm{g} / \mathrm{mL}$ ) genistein was adequate to inhibit growth of $90 \%$ human mammary cancer cell MCF-10F. 
Kumi-Diaka [10] depicted that the human prostate cancer cell (PC-3 and LNCaP) could be retarded by genistein at 10, 30, 50 and $70 \mu \mathrm{g} / \mathrm{mL}$, with a high inhibition $(90-100 \%)$ attained at $70 \mu \mathrm{g} / \mathrm{mL}$. Likewise, the $\mathrm{IC}_{50}$ of genistein in inhibiting Chinese hamster liver fibroblast cancer cell (V79) was 75 $\mu \mathrm{M}(20.3 \mu \mathrm{g} / \mathrm{mL})$ [12]. However, a complete inhibition (100\%) of human prostate cancer cell (DU 145) occurred for genistein at 50, 75 and $100 \mu \mathrm{M}$ [13]. All these results further proved that the inhibition efficiency of various carcinoma cells can be dependent upon the level of genistein.

\subsection{Cell cycle analysis}

Figure 2 and Table 3 show the cell cycle and proportion of cells at sub-G0/G1, G0/G1, S and G2/ $\mathrm{M}$ phases as affected by isoflavone fractions and extracts as well as standards. The ratio of sub-G0/G1 increased with increasing concentrations of isoflavone fractions and extracts as well as standards, indicating a large proportion of cell may undergo apoptosis. A higher ratio of sub-G0/G1 was shown for ISO-2, $2 \mathrm{std}, 4 \mathrm{std}$ and genistein at a dose of $10 \mu \mathrm{g} / \mathrm{mL}$. Likewise, the 4 std treatment showed the highest sub-G0/G1 ratio at $30 \mu \mathrm{g} / \mathrm{mL}$, followed by ISO-2, acetylglucoside, aglycone, 2 std, genistein and acetylgenistin, whereas the other treatments only showed minor change. With concentration at 50 $\mu \mathrm{g} / \mathrm{mL}$, a similar trend occurred in the ratio of sub-G0/G1 for $2 \mathrm{std}, 4$ std, genistein, acetylgenistin, ISO-2 and aglycone, but there were no significant difference between any of these treatments.

In contrast to sub-G0/G1, the ratio of $\mathrm{G} 0 / \mathrm{G} 1$ declined following a rise in concentrations of isoflavone fractions and extracts as well as standards, indicating the G0/G1 phase of cell cycle regulation was not perturbated. A low dose of $10 \mu \mathrm{g} / \mathrm{mL}$ resulted in the $\mathrm{G} 0 / \mathrm{G} 1$ ratio of all the treatments being significantly lower than control treatment, but with a slight difference among these treatments. The lowest G0/G1 ratio was shown for 4 std, followed by ISO-2, aglycone, genistein, genistin, 2 std, ISO-1, malonylglucoside, daidzein, acetylglucoside, malonygenistin, acetylgenistin and glucoside. A similar tendency occurred for both doses at 30 and $50 \mu \mathrm{g} / \mathrm{mL}$, with a low $\mathrm{G} 0 / \mathrm{G} 1$ ratio for 4 std, 2 std, aglycone, ISO-2, acetylglucoside and genistein.

Like $\mathrm{G} 0 / \mathrm{G} 1$, the ratio of $\mathrm{S}$ phase decreased along with increasing concentrations of isoflavone fractions and extracts as well as standards, revealing the stage of DNA synthesis was retarded. Only a slight change in S phase ratio was observed at $10 \mu \mathrm{g} / \mathrm{mL}$. However, with doses at 30 and $50 \mu \mathrm{g} / \mathrm{mL}$, most treatments showed a lower $\mathrm{S}$ phase ratio than the control treatment.

In contrast to $\mathrm{S}$ phase, the ratio of $\mathrm{G} 2 / \mathrm{M}$ phase rose following an increase in concentrations of isoflavone fractions and extracts as well as standards, implying the cell mitosis stage was inhibited at concentrations of 10,30 and $50 \mu \mathrm{g} / \mathrm{mL}$. The difference in $\mathrm{G} 2 / \mathrm{M}$ ratio was minor at low dose (10 $\mu \mathrm{g} / \mathrm{mL}$ ) between isoflavone fractions or extracts and standards. However, a large difference occurred at 30 and $50 \mu \mathrm{g} / \mathrm{mL}$, especially for the latter, with 4 std showing the highest $\mathrm{G} 2 / \mathrm{M}$ ratio $(64.2 \%)$, followed by aglycone (57.3\%), 2 std (52.4\%), ISO-2 (52.0\%), acetylglucoside (45.5\%) and genistein $(37.4 \%)$, and the other treatments showed a low G2/M ratio ranging from $24.1-27.4 \%$.

The cell cycle study results clearly demonstrated that both aglycone and acetylglucoside fractions as well as a mixture of isoflavone standards were more effective in inhibiting HepG2 cell growth than the other treatments. Many studies also indicated that the G2/M ratio could be increased greatly in the presence of isoflavone standards such as genistein and daidzein, with the former being more effective [9,11,17,24-27]. The mechanism in inhibiting tumor cell growth by genistein has been attributed to 
retardation of activities of protein tyrosine kinase, topoisomerase I and II, $5 \alpha$-reductase, focal adhesion kinase and protein histidine kinase [28,29], promotion of tumor suppressor gene expression like P53 and P21 [9,13] and formation of cyclin-dependent kinase inhibitor [9,11], regulation of Bax and Bcl-2 gene expression [27] and transcription factor NF-KB binding activity [29], inhibition of Akt and androgen receptor [29] as well as angiogenesis and metastasis [30,31], enhancement of connexin 43 expression [32] and antioxidant activity [18, 20-22].

Figure 2. Flow cytometric analysis of Hep G2 cells treated with isoflavone fractions and extracts as well as standards.M: malonylglucoside fraction; G: glucoside fraction; Ac: acetylglucoside fraction; Ag: aglycone fraction; ISO-1: soybean cake extract containing 12 isoflavones; ISO-2: a combination of four groups of isoflavone fractions; Mgin: malonylgenistin; Gin: genistin; Agin: acetylgenistin; Gein: genistein; Dein: daidzein; 2 std: a combination of daidzein and genistein; 4 std: a combination of malonylgenistin, genistin, acetylgenistin and genistein. a: sub-G0/G1; b: G0/G1; c: S; d: G2/M.

\section{$10 \mu \mathrm{g} / \mathrm{mL}$}
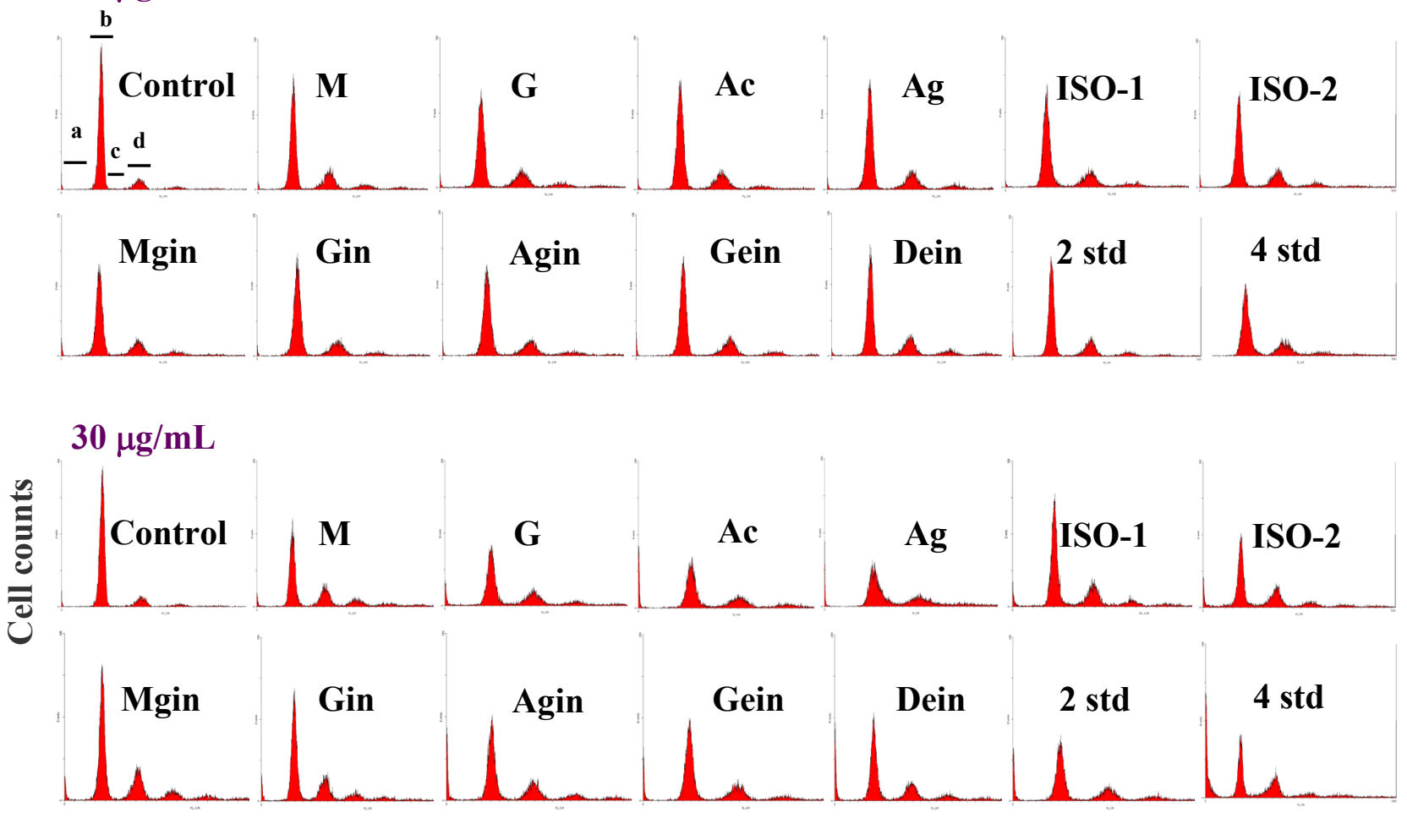

$50 \mu \mathrm{g} / \mathrm{mL}$

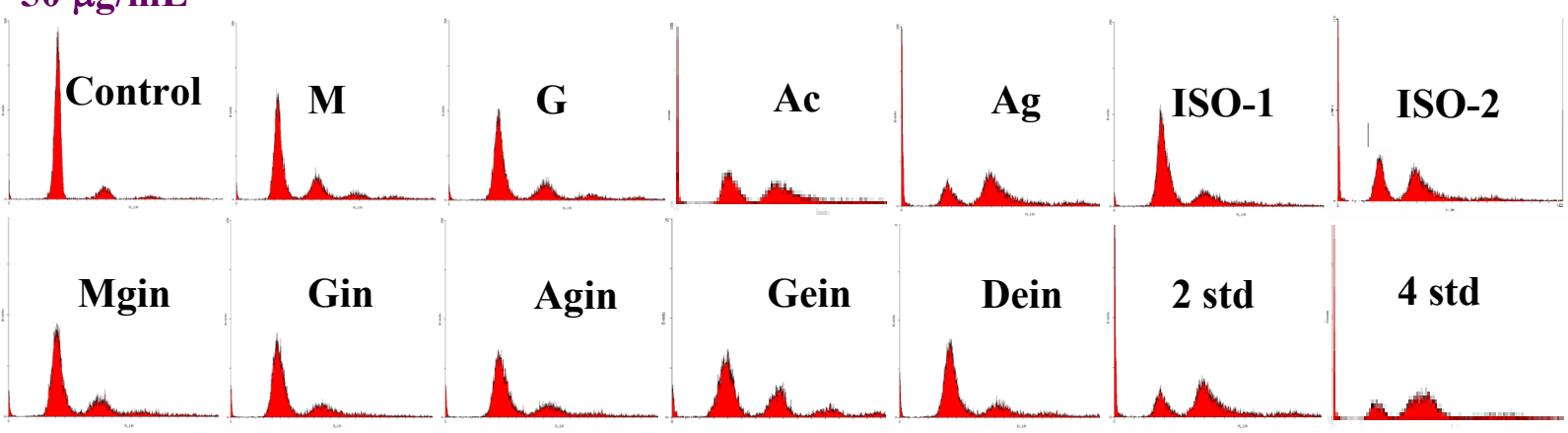


In addition to isoflavone, the presence of saponin in acetylglucoside fraction may also play an important role in inhibiting cancer cell growth. Kim et al. [33] reported that soy saponins may inhibit colon cancer cell growth through retardation of $\mathrm{IkB} \alpha$ degradation and decrease of cyclooxygenase- 2 and protein kinase $\mathrm{C}$ expression. A similar outcome was also observed by Ellington et al. [34,35], who found that the colon cancer cell HTC-15 was accumulated at S phase of cell cycle in the presence of soy saponins.

Table 3. Effect of isoflavone fractions and extracts as well as standards on cell cycle distribution of Hep G2 cells ${ }^{\mathrm{A}}$.

\begin{tabular}{|c|c|c|c|c|c|c|c|c|c|c|c|c|}
\hline \multirow[t]{2}{*}{ Isoflavone } & \multicolumn{3}{|c|}{ sub-G0/G1 (\%) } & \multicolumn{3}{|c|}{ G0/G1 (\%) } & \multicolumn{3}{|c|}{ S (\%) } & \multicolumn{3}{|c|}{ G2/M (\%) } \\
\hline & $10 \mu \mathrm{g} / \mathrm{mL}$ & $30 \mu \mathrm{g} / \mathrm{mL}$ & $50 \mu \mathrm{g} / \mathrm{mL}$ & $10 \mu \mathrm{g} / \mathrm{mL}$ & $30 \mu \mathrm{g} / \mathrm{mL}$ & $50 \mu \mathrm{g} / \mathrm{mL}$ & $10 \mu \mathrm{g} / \mathrm{mL}$ & $30 \mu \mathrm{g} / \mathrm{mL}$ & $50 \mu \mathrm{g} / \mathrm{mL}$ & $10 \mu \mathrm{g} / \mathrm{mL}$ & $30 \mu \mathrm{g} / \mathrm{mL}$ & $50 \mu \mathrm{g} / \mathrm{mL}$ \\
\hline Control & $2.2 \pm 0.1 \mathrm{eA}$ & $2.3 \pm 0.3 \mathrm{hA}$ & $2.2 \pm 0.3 \mathrm{eA}$ & $80.4 \pm 1.7 \mathrm{aA}$ & $80.7 \pm 2.0 \mathrm{aA}$ & $80.5 \pm 1.3 \mathrm{aA}$ & $6.6 \pm 0.6 \mathrm{aA}$ & $6.8 \pm 0.4 \mathrm{aA}$ & $6.8 \pm 0.9 \mathrm{aA}$ & $10.9 \pm 0.6 \mathrm{cA}$ & $10.2 \pm 1.3 \mathrm{gA}$ & $10.5 \pm 2.3 \mathrm{fA}$ \\
\hline M & $3.1 \pm 0.1 \mathrm{~dB}$ & $4.9 \pm 0.2 \mathrm{gA}$ & $5.7 \pm 0.5 \mathrm{dA}$ & $73.0 \pm 1.6 \mathrm{bA}$ & $67.1 \pm 3.4 \mathrm{bAB}$ & $63.8 \pm 2.6 \mathrm{bC}$ & $6.1 \pm 0.3 \mathrm{aA}$ & $5.6 \pm 0.6 \mathrm{bA}$ & $5.1 \pm 0.2 \mathrm{bAB}$ & $17.8 \pm 1.8 \mathrm{abB}$ & $22.4 \pm 2.6 \mathrm{def} A B$ & $25.4 \pm 2.5 \mathrm{eA}$ \\
\hline G & $3.3 \pm 0.3 \mathrm{cdB}$ & $6.1 \pm 0.2 \mathrm{de} A$ & $6.0 \pm 0.1 \mathrm{cdA}$ & $74.5 \pm 0.8 \mathrm{bA}$ & $67.5 \pm 0.9 \mathrm{bB}$ & $65.0 \pm 1.6 \mathrm{bB}$ & $5.4 \pm 0.1 \mathrm{bA}$ & $5.3 \pm 0.7 \mathrm{bAB}$ & $4.9 \pm 0.1 \mathrm{bB}$ & $16.8 \pm 1.2 \mathrm{abB}$ & $21.1 \pm 1.4 \mathrm{efA}$ & $24.1 \pm 1.4 \mathrm{eA}$ \\
\hline Ac & $3.2 \pm 0.4 \mathrm{cdC}$ & $7.4 \pm 0.8 \mathrm{cB}$ & $10.1 \pm 1.2 \mathrm{aA}$ & $73.1 \pm 1.6 \mathrm{bA}$ & $61.0 \pm 3.6 \mathrm{cdB}$ & $39.5 \pm 1.2 \mathrm{dC}$ & $6.7 \pm 0.7 \mathrm{aA}$ & $5.1 \pm 1.0 \mathrm{bAB}$ & $5.0 \pm 0.3 \mathrm{bB}$ & $17.0 \pm 1.5 \mathrm{abC}$ & $26.5 \pm 1.8 \mathrm{bcdB}$ & $45.5 \pm 3.1 \mathrm{cA}$ \\
\hline $\mathrm{Ag}$ & $2.7 \pm 0.4 \mathrm{deC}$ & $7.2 \pm 0.3 \mathrm{cdB}$ & $9.8 \pm 1.2 \mathrm{aA}$ & $71.4 \pm 0.0 \mathrm{bcA}$ & $58.4 \pm 2.0 \mathrm{~dB}$ & $27.9 \pm 4.0 \mathrm{eC}$ & $6.1 \pm 1.2 \mathrm{abAB}$ & $6.1 \pm 0.3 \mathrm{aA}$ & $5.0 \pm 0.4 \mathrm{bB}$ & $19.8 \pm 0.8 \mathrm{abC}$ & $28.3 \pm 2.0 \mathrm{bcB}$ & $57.3 \pm 4.0 \mathrm{bA}$ \\
\hline ISO-1 & $3.4 \pm 0.2 \mathrm{cdC}$ & $5.0 \pm 0.1 \mathrm{fgB}$ & $6.3 \pm 0.7 \mathrm{cdA}$ & $72.7 \pm 2.9 \mathrm{bcA}$ & $69.0 \pm 2.8 \mathrm{bA}$ & $61.7 \pm 1.4 \mathrm{bB}$ & $6.0 \pm 0.7 \mathrm{abA}$ & $4.6 \pm 0.9 \mathrm{bAB}$ & $4.6 \pm 0.5 \mathrm{bB}$ & $18.0 \pm 2.6 \mathrm{abB}$ & $21.4 \pm 1.9 \mathrm{efAB}$ & $27.4 \pm 1.5 \mathrm{eA}$ \\
\hline ISO-2 & $5.3 \pm 0.6 \mathrm{aC}$ & $9.1 \pm 0.2 \mathrm{bB}$ & $10.0 \pm 0.6 \mathrm{aA}$ & $70.9 \pm 1.2 \mathrm{bcA}$ & $61.1 \pm 2.3 \mathrm{cdB}$ & $33.5 \pm 3.0 \mathrm{eC}$ & $6.1 \pm 0.4 \mathrm{abA}$ & $4.8 \pm 0.6 \mathrm{bB}$ & $4.5 \pm 1.0 \mathrm{bB}$ & $17.6 \pm 1.7 \mathrm{abB}$ & $25.0 \pm 2.7 \mathrm{cdeB}$ & $52.0 \pm 3.3 \mathrm{bA}$ \\
\hline Mgin & $4.3 \pm 0.4 \mathrm{bC}$ & $5.5 \pm 0.5 \mathrm{efgB}$ & $6.8 \pm 0.1 \mathrm{bcdA}$ & $73.2 \pm 1.7 \mathrm{bA}$ & $67.5 \pm 1.6 \mathrm{bB}$ & $62.5 \pm 1.6 \mathrm{bC}$ & $6.3 \pm 1.1 \mathrm{abA}$ & $6.3 \pm 0.5 \mathrm{aA}$ & $5.0 \pm 0.5 \mathrm{abA}$ & $16.2 \pm 1.7 \mathrm{bC}$ & $20.7 \pm 0.6 \mathrm{efB}$ & $25.7 \pm 0.6 \mathrm{eA}$ \\
\hline Gin & $4.5 \pm 0.4 \mathrm{abC}$ & $5.3 \pm 0.2 \mathrm{efgB}$ & $6.6 \pm 0.4 \mathrm{cdA}$ & $71.9 \pm 1.8 \mathrm{bcA}$ & $69.2 \pm 3.6 \mathrm{bB}$ & $63.9 \pm 0.1 \mathrm{bC}$ & $6.5 \pm 1.7 \mathrm{abA}$ & $6.1 \pm 1.2 \mathrm{aA}$ & $5.1 \pm 0.2 \mathrm{bA}$ & $17.1 \pm 1.2 \mathrm{abB}$ & $19.5 \pm 2.2 \mathrm{fAB}$ & $24.5 \pm 2.2 \mathrm{eA}$ \\
\hline Agin & $4.4 \pm 0.5 \mathrm{bC}$ & $6.3 \pm 0.5 \mathrm{cdeB}$ & $8.2 \pm 0.6 \mathrm{bA}$ & $73.4 \pm 0.3 \mathrm{bA}$ & $64.4 \pm 1.2 \mathrm{bcB}$ & $60.4 \pm 1.1 \mathrm{bC}$ & $5.7 \pm 0.7 \mathrm{abA}$ & $5.4 \pm 0.7 \mathrm{bA}$ & $4.4 \pm 0.8 \mathrm{bA}$ & $16.5 \pm 1.6 \mathrm{abB}$ & $24.0 \pm 1.4 \mathrm{defA}$ & $27.0 \pm 2.4 \mathrm{eA}$ \\
\hline Gein & $4.5 \pm 0.3 \mathrm{abC}$ & $6.5 \pm 0.7 \mathrm{cdeB}$ & $10.6 \pm 0.9 \mathrm{aA}$ & $71.6 \pm 1.4 \mathrm{bcA}$ & $57.5 \pm 1.0 \mathrm{~dB}$ & $47.9 \pm 1.4 \mathrm{cC}$ & $6.3 \pm 0.9 \mathrm{abA}$ & $6.7 \pm 0.8 \mathrm{aA}$ & $4.1 \pm 0.3 \mathrm{bB}$ & $17.6 \pm 0.8 \mathrm{abC}$ & $29.4 \pm 2.4 \mathrm{bB}$ & $37.4 \pm 3.2 \mathrm{dA}$ \\
\hline Dein & $4.0 \pm 0.1 \mathrm{bcC}$ & $6.1 \pm 0.3 \mathrm{defB}$ & $7.4 \pm 0.8 \mathrm{bcA}$ & $73.1 \pm 2.7 \mathrm{bcA}$ & $69.5 \pm 0.2 \mathrm{bB}$ & $64.2 \pm 3.9 \mathrm{bC}$ & $6.2 \pm 0.9 \mathrm{abA}$ & $5.0 \pm 0.1 \mathrm{bA}$ & $4.9 \pm 0.1 \mathrm{bB}$ & $16.8 \pm 2.5 \mathrm{abB}$ & $19.5 \pm 0.2 \mathrm{fAB}$ & $23.5 \pm 2.2 \mathrm{eA}$ \\
\hline 2 std & $4.7 \pm 0.3 \mathrm{abC}$ & $6.8 \pm 0.7 \mathrm{cdB}$ & $11.1 \pm 0.8 \mathrm{aA}$ & $71.9 \pm 0.2 \mathrm{bA}$ & $57.5 \pm 1.9 \mathrm{~dB}$ & $32.3 \pm 4.2 \mathrm{eC}$ & $6.0 \pm 0.7 \mathrm{abA}$ & $5.2 \pm 0.6 \mathrm{bA}$ & $4.2 \pm 0.8 \mathrm{bB}$ & $17.4 \pm 0.3 \mathrm{abC}$ & $30.4 \pm 0.6 \mathrm{bB}$ & $52.4 \pm 2.8 \mathrm{bA}$ \\
\hline 4 std & $4.6 \pm 0.5 \mathrm{abC}$ & $11.0 \pm 1.1 \mathrm{aA}$ & $11.1 \pm 0.2 \mathrm{aA}$ & $69.3 \pm 1.9 \mathrm{cA}$ & $48.8 \pm 2.1 \mathrm{eB}$ & $19.9 \pm 3.5 \mathrm{fC}$ & $6.1 \pm 0.3 \mathrm{aA}$ & $5.1 \pm 1.6 \mathrm{bAB}$ & $4.8 \pm 0.2 \mathrm{bB}$ & $20.0 \pm 1.1 \mathrm{aC}$ & $35.2 \pm 2.6 \mathrm{aB}$ & $64.2 \pm 3.6 \mathrm{aA}$ \\
\hline
\end{tabular}

${ }^{\mathrm{A}}$ Average of duplicate analyses \pm standard deviation. Symbols bearing different letters (a-g) in the same column are significantly different $(\mathrm{P}<0.05)$. Symbols bearing different letters $(\mathrm{A}-\mathrm{C})$ in the same row within each period of cell cycle are significantly different $(\mathrm{P}<0.05)$. M: malonylglucoside fraction; G: glucoside fraction; Ac: acetylglucoside fraction; Ag: aglycone fraction; ISO-1: soybean cake extract containing 12 isoflavones; ISO-2: a combination of four groups of isoflavone fractions; Mgin: malonylgenistin; Gin: genistin; Agin: acetylgenistin; Gein: genistein; Dein: daidzein; 2 std: a combination of daidzein and genistein; 4 std: a combination of malonylgenistin, genistin, acetylgenistin and genistein.

Most human studies of isoflavones dealt with inhibition of osteoporosis, alleviation of menopause syndrome and reduction of blood triacylglycerol. Dalais et al. [36] reported that a daily supply of 117 mg isoflavone could lower the level of prostate-specific antigen in blood of male with prostate cancer. Similarly, a supply of isoflavone at $160 \mathrm{mg}$ /day for one week prior to prostate surgery could lead to mortality of prostate cancer cell without any side effect [37]. In a recent human study the maximum isoflavone concentration in blood was determined to be $0.64 \mu \mathrm{M}$ when a dose of $1 \mu \mathrm{mole} / \mathrm{kg} \mathrm{BW}$ genistein was provided. Of the various isoflavone fractions in our experiment, the $\mathrm{IC}_{50}$ for the most effective acetylglucoside and aglycone were 19.9 and $8.8 \mu \mathrm{g} / \mathrm{mL}$, respectively, which is equivalent to a dose of genistein at 31.6 and $14.0 \mathrm{mg} / \mathrm{kg} \mathrm{BW}$. Although this level was higher than those reported in the literature, it should not be toxic to human. But for cancer inhibition by isoflavones, both animal and cell models were frequently conducted. No systemic toxicity occurred in rat for genistein and daidzein at a dose of 140 and $250 \mathrm{mg} / \mathrm{kg} \mathrm{BW}$, respectively [38]. Likewise, a higher level of genistein at 500 or 
$2000 \mathrm{mg} / \mathrm{kg}$ was shown not to cause embryo teratogenesis for the former and genetic toxicity for the latter $[39,40]$. Thus, it is apparent that the doses of acetylglucoside $(31.6 \mathrm{mg} / \mathrm{kg} \mathrm{BW} /$ day $)$ and aglycone $(14.0 \mathrm{mg} / \mathrm{kg} \mathrm{BW} /$ day) used in our study should not induce toxicity to both animal and human. In conclusion, both aglycone and acetylglucoside fractions prepared from soybean cake were more effective in HepG2 cancer cell antiproliferation than the other isoflavone fractions and extracts. A mixture of isoflavone standards showed a better inhibition than single isoflavone standard. For cell cycle study, both aglycone and acetylglucoside fractions as well as a mixture of isoflavone standards possessed a high G2/M ratio, correlating well with the result of MTT test.

\section{Experimental Section}

\subsection{Materials}

A total of $50 \mathrm{Kg}$ of soybean cake was procured from Chong-Liang Oil Co. (Taichung, Taiwan). Isoflavone standards, malonylgenistin, genistin, acetylgenistin, genistein and daidzein were obtained from LC laboratories (Woburn, MA, USA). Reagents, including phosphate buffered saline (PBS), fetal bovine serum (FBS), trypsin blue stain $(0.4 \%)$, 2.5\% trypsin-EDTA, Hank's balanced salt solution (HBSS) and penicillin-streptomycin were from Gibco Co. (California, USA). Minimum essential medium alpha modification ( $\alpha$-MEM), dimethyl sulfoxide (DMSO), hypoxanthin, thymidine, sodium bicarbonate, fungizone (amphotericin B solution), 3-(4,5-dimethylthiazole)-2,5-diphenyltetrazolium bromide (MTT), RNase A and propidium iodide were from Sigma Co. (St. Louis, MO, USA). Ethanol (95\%) was from Taiwan Tobacco Co. (Tainan, Taiwan). Deionized water was made using a Milli-Q water purification system from Millipore Co. (Bedford, MA, USA). Human hepatoma cell line (HepG2) was from Taiwan Food Industry Development Institute/National Health Research Institute (Hsinchu, Taiwan).

\subsection{Preparation of isoflavone extracts and fractions from soybean cake}

A method based on Kao et al. (41) was used to prepare isoflavone extracts from soybean cake. Briefly, soybean cake powder $(50 \mathrm{~g})$ was mixed with aqueous ethanol solution $(50 \%, 150 \mathrm{~mL})$. Then the mixture was shaken at room temperature for $2 \mathrm{~h}$ and centrifuged at $6000 \mathrm{rpm}\left(25^{\circ} \mathrm{C}\right)$ for $20 \mathrm{~min}$, followed by collecting the supernatant and filtering through a glass filter paper to obtain the isoflavone extract (ISO-1). For preparation of four isoflavone fractions, Diaion HP-20 resin (200 g) was poured into a glass column (375 x $45 \mathrm{~mm}$ I.D.) and pre-activated with ethanol (1 L) and deionized water $(1 \mathrm{~L})$. Then, an isoflavone extract $(80 \mathrm{~mL})$ was poured into the column and high-polar impurities were eluted with deionized water $(400 \mathrm{~mL})$, followed by subsequent elution of malonylglucoside and glucoside fractions with $15 \%$ aqueous ethanol solution $(900 \mathrm{~mL})$ and $27 \%$ aqueous ethanol solution $(3300 \mathrm{~mL})$, respectively, at a flow rate of $10 \mathrm{~mL} / \mathrm{min}$. Both acetylglucoside and aglycone fractions were eluted with $70 \%$ aqueous ethanol solution $(200 \mathrm{~mL})$ and $95 \%$ aqueous ethanol solution $(400 \mathrm{~mL})$, respectively. Because of overlapping by HPLC analysis, both acetylglucoside and aglycone fractions were combined and evaporated to dryness, dissolved in isopropanol $(20 \mathrm{~mL})$ and a portion $(10 \mathrm{~mL})$ was poured onto a Yamazen Hi-Flash ${ }^{\mathrm{TM}}$ silica gel column $(170 \times 48 \mathrm{~mm}$ I.D.) for elution of these two fractions separately with hexane-isopropanol-ethanol $(8: 9: 1, \mathrm{v} / \mathrm{v} / \mathrm{v})$ and flow rate at $20 \mathrm{~mL} / \mathrm{min}$. All the 
four isoflavone fractions were also combined (ISO-2) for subsequent cell proliferation study. The variety and amount of isoflavones in each fraction was analyzed by HPLC using a method described by Hsieh et al. [42]. In addition, some other functional components like saponins, phenolic compounds and total flavonoids in each fraction were determined based on a procedure as described by Kao and Chen [14]. Total phenolic compounds were present at a level ranged from 142.3-319.2 $\mu \mathrm{g} / \mathrm{mL}$ in all the isoflavone fractions and extracts, while total flavonoids were $1.82-26.44 \mu \mathrm{g} / \mathrm{mL}$. With the exception of malonylglucoside fraction, saponins (soyasapogenol A and soyasapogenol B) were also present at $14.75-372.23 \mu \mathrm{g} / \mathrm{mL}$ in the other isoflavone fractions and extracts.

\subsection{Preparation of isoflavone extracts and fractions for cell antiproliferation study}

A sample of isoflavone extract (ISO-1), malonylglucoside and glucoside fractions (20 mL each) was collected separately, evaporated to dryness and dissolved in water-ethanol (1:1, v/v, $2 \mathrm{~mL})$. A sample $(20 \mu \mathrm{L})$ was mixed with internal standard formononetin $(200 \mu \mathrm{g} / \mathrm{mL}, 200 \mu \mathrm{L})$ and water-ethanol $(1: 1$, $\mathrm{v} / \mathrm{v}, 1780 \mu \mathrm{L}$ ), followed by filtering the mixture through a $0.2-\mu \mathrm{m}$ membrane filter and $20 \mu \mathrm{L}$ was injected for HPLC analysis. After quantitation, ISO-1 was found to contain isoflavone at 15844.8 $\mu \mathrm{g} / \mathrm{mL}$, whereas malonylglucoside fraction contained isoflavone at $12471.3 \mu \mathrm{g} / \mathrm{mL}$ and glucoside fraction at $9884.0 \mu \mathrm{g} / \mathrm{mL}$. Next, a volume of ISO-1 $(632 \mu \mathrm{L})$, malonylglucoside fraction $(802 \mu \mathrm{L})$ and glucoside fraction $(1012 \mu \mathrm{L})$ was collected separately and mixed with 1368, 1198 and $988 \mu \mathrm{L}$ of water-ethanol $(1: 1, \mathrm{v} / \mathrm{v})$, with the total volume of $2 \mathrm{~mL}$ each and the final isoflavone concentrations being 5007, 5001 and $5001 \mu \mathrm{g} / \mathrm{mL}$, respectively.

Both acetylglucoside and aglycone fractions were collected five times from a preparative column as described above separately, pooled and evaporated to dryness. The residue was dissolved in waterethanol $(1: 1, \mathrm{v} / \mathrm{v}, 2 \mathrm{~mL})$, and a portion $(20 \mu \mathrm{L})$ was mixed with internal standard formononetin (200 $\mu \mathrm{g} / \mathrm{mL}, 200 \mu \mathrm{L})$ and water-ethanol $(1: 1, \mathrm{v} / \mathrm{v}, 1780 \mu \mathrm{L})$, after which the mixture was filtered through a 0.2- $\mu \mathrm{m}$ membrane filter and $20 \mu \mathrm{L}$ was injected for HPLC analysis. After quantitation, both acetylglucoside and aglycone fractions were shown to contain isoflavones at 5530.7 and 6004.8 $\mu \mathrm{g} / \mathrm{mL}$, respectively. Again, a volume of acetylglucoside $(1810 \mu \mathrm{L})$ and aglycone $(1660 \mu \mathrm{L})$ was mixed with water-ethanol (1:1, v/v, 190 and $340 \mu \mathrm{L}$, respectively), for a total volume of $2 \mathrm{~mL}$ each with isoflavone levels being 5005 and $5002 \mu \mathrm{g} / \mathrm{mL}$. For preparation of the other isoflavone extract (ISO-2), a volume of $500 \mu \mathrm{L}$ malonylglucoside, glucoside, acetylglucoside and aglycone was collected separately and combined for a total volume of $2 \mathrm{~mL}$ containing isoflavone at $5002 \mu \mathrm{g} / \mathrm{mL}$.

\subsection{Preparation of isoflavone standards for cell antiproliferation study}

A standard (10 mg) of daidzein, malonylgenistin, genistin, acetylgenistin and genistein was mixed with water-ethanol $(1: 1, \mathrm{v} / \mathrm{v})$ separately for a total volume of $2 \mathrm{~mL}$ containing isoflavone at 5000 $\mu \mathrm{g} / \mathrm{mL}$ each. These standards were used alone or combined to $2 \mathrm{std}$ (daidzein and genistein) and 4 std (malonylgenistin, genistin, acetylgenistin and genistein) for subsequent cell antiproliferation study. 


\subsection{Preparation of final isoflavone concentration}

A volume of $1.5 \mathrm{~mL}$ was collected from four isoflavone fractions, two isoflavone extracts (ISO-1 and ISO-2), malonylgenistin, genistin, acetylgenistin, genistein, 2 std and 4 std separately, followed by mixing with $\alpha$-MEM medium $(148.5 \mathrm{~mL})$ and filtering through a $0.2-\mu \mathrm{m}$ membrane filter for an isoflavone level at $50 \mu \mathrm{g} / \mathrm{mL}$ each. Again, a volume of 40, 30, 20, 10 and $5 \mathrm{~mL}$ medium was collected and mixed with 10,20,30, 40 and $45 \mathrm{~mL} \alpha$-MEM medium for a final isoflavone concentration at 40 , $30,20,10$ and $5 \mu \mathrm{g} / \mathrm{mL}$, respectively.

\subsection{Cell culture}

HepG2 human hepatoma cells were cultured in $\alpha$-MEM medium ( $\mathrm{pH} 7.4$ ) supplemented with $10 \%$ fetal bovine serum (FBS), $36 \mu \mathrm{M}$ hypoxanthin, $36 \mu \mathrm{M}$ thymidine, $0.5 \%$ fungizone and $1 \%$ penicillinstreptomycin. Cells were incubated at $37^{\circ} \mathrm{C}$ under $5 \% \mathrm{CO}_{2}$ humidified atmosphere and replaced every two days to maintain normal growth. Prior to MTT and cell cycle experiments, cells have to undergo solvent endurability and growth stability test and our result indicated that a culture medium containing $0.5 \%$ ethanol would not affect normal cell growth as the activity still maintained even after $72 \mathrm{~h}$ incubation.

\subsection{MTT test}

HepG2 cells were grown to the desired density at about $80 \%$ confluence and washed with $2 \mathrm{~mL}$ PBS twice, followed by adding $0.5 \mathrm{~mL} 2.5 \%$ trypsin-EDTA. The solution was shaken gently to cover cell surface and placed into an incubator for 1-2 min until floating, after which $1 \mathrm{~mL} \alpha$-MEM medium was added for neutralization and cells were harvested, then transferred to a $15 \mathrm{~mL}$ tube for centrifugation at $2000 \mathrm{rpm}$ for $5 \mathrm{~min}$. The supernatant was collected and $2 \mathrm{~mL} \alpha$-MEM medium added to suspend cells, and an appropriate amount of cell medium was collected and diluted for calculation. For MTT test, a $0.2 \mathrm{~mL}$ HepG 2 cell suspension was seeded at a cell density of about $4 \times 10^{4}$ cell/plate to 96 -well plates $\left(100 \mu \mathrm{L}\right.$ medium/well) and cultured for $24 \mathrm{~h}$ at $37{ }^{\circ} \mathrm{C}$ under $5 \% \mathrm{CO}_{2}$ so that cells were attached to the bottom. The culture medium was sucked and replaced with isoflavone extracts and fractions as well as standards at six concentrations of 5, 10, 20, 30, 40 and $50 \mu \mathrm{g} / \mathrm{mL}$. Triplicate wells were used for each concentration. After incubation for $72 \mathrm{~h}, 0.2-\mathrm{mL}$ of MTT $(0.5 \mathrm{mg} / \mathrm{mL}$ in HBSS) was added and further cultured for $3 \mathrm{~h}$ at $37{ }^{\circ} \mathrm{C}$ in the dark. After removal of MTT solution, 0.2 $\mathrm{mL}$ dimethyl sulfoxide was added to dissolve purple crystal for $15 \mathrm{~min}$, after which the absorbance of the solution was measured at $570 \mathrm{~nm}$ with an ELISA reader. The inhibition effect of HepG2 cell growth was expressed as relative cell survival percentage:

$$
\text { Relative cell survival rate }(\%)=\frac{\begin{array}{l}
\text { Absorbance of the solution } \\
\text { after reaction with isoflavone }
\end{array}}{\begin{array}{c}
\text { Absorbance of the solution } \\
\text { before reaction with isoflavone }
\end{array}} \times 100
$$


The $\mathrm{IC}_{50}$ value was also calculated based on the regression equation of the curve obtained by plotting concentration against cell survival rate.

\subsection{Cell cycle analysis}

A method based on Chang et al. [11] was slightly modified to study cell cycle analysis. Cells were seeded at a density of about $1 \times 10^{6}$ cell to culture plate. After incubation for $24 \mathrm{~h}$, all the isoflavone extracts and fractions as well as standards were added at a concentration of $0,10,30$ and $50 \mu \mathrm{g} / \mathrm{mL}$ and cultured for another $24 \mathrm{~h}$. The cells were then subjected to trypsinization with trypsin-EDTA and washed with PBS, followed by centrifuging at $2000 \mathrm{rpm}$ for $5 \mathrm{~min}$. The supernatant was collected and 1 -mL PBS solution containing $70 \%$ ethanol was added for cell fixation at $4{ }^{\circ} \mathrm{C}$ overnight. The mixture was centrifuged to remove PBS solution and cells were washed again with PBS, after which $0.1 \mathrm{~mL}$ RNase A PBS solution $(100 \mu \mathrm{g} / \mathrm{mL})$ was added. The mixture was reacted in a water bath at $37^{\circ} \mathrm{C}$ for $30 \mathrm{~min}$ and $0.1 \mathrm{~mL}$ propidium iodide $(10 \mu \mathrm{g} / \mathrm{mL})$ was added for cell cycle analysis by using a flow cytometer (Beckman Coulter EPICS XL-MCL).

\subsection{Statistical analysis}

Triplicate analyses were performed for MTT test while duplicate experiments were carried out for flow cytometry. All the data were subjected to analysis of variance using ANOVA and Duncan's multiple range test for significant difference comparison $(\alpha=0.05)$ by using SAS [43].

\section{References and Notes}

1. World Cancer Research Fund, American Institute for Cancer Research. Food, nutrition and the prevention of cancer: a global perspective; American Institute for Cancer Research: Washington, 1997.

2. Adlercreutz, H. Phyto-oestrogens and cancer. Lancet Oncol. 2002, 3, 364-372.

3. Block, G.; Patterson, B.; Subar, A. Fruits, vegetables, and cancer prevention: a review of the epidemiological evidence. Nutr. Cancer. 1992, 18, 1-29.

4. Messina, M.; Deshcheemaker, K.; Erdman, J.W. The role of soy in preventing and treating chronic disease. Am. J. Clin. Nutr. 1998, 68, 1329-1544.

5. Adlercreutz, H.; Honjo, H.; Higash, A. Urinary excretion of lignans and isoflavonoid phytoestrogens in Japanese men and women consuming traditional Japanese diet. Am. J. Clin. Nutr. 1991, 54, 1093-1100.

6. Dixon, R.A.; Ferreira, D. Genistein. Phytochemistry 2002, 60, 205-211.

7. Peterson, G.; Barnes, S. Genistein inhibition of the growth of human breast cancer cells: Independence from estrogen receptors and the multi-drug resistance gene. Biochem. Biophys. Res. Commun. 1991, 179, 661-667.

8. Scholar, E.M.; Toews, M.L. Inhibition of invasion of murine mammary carcinoma cells by the tyrosine kinase inhibitor genistein. Cancer Lett. 1994, 87, 159-162. 
9. Frey, R.S.; Li, J.; Singletary, K.W. Effects of genistein on cell proliferation and cell cycle arrest in nonneoplastic human mammary epithelial cells involvement of $\mathrm{Cdc} 2, \mathrm{p} 21^{\text {waf/cip } 1}, \mathrm{p} 27^{\mathrm{kip} 1}$, and Cdc25C expression. Biochem. Pharmacol. 2001, 61, 979-989.

10. Kumi-Diaka, J. Chemosensitivity of human prostate cancer cells PC3 and LNCaP to genistein isoflavone and $\beta$-lapachone. Bio. Cell. 2002, 94, 37-44.

11. Chang, K.L.; Kung, M.L.; Chow, N.H.; Su, S.J. Genistein arrests hepatoma cells at G2/M phase: involvement of ATM activation and upregulationof $\mathrm{p} 21^{\mathrm{waf} 1 / \mathrm{cip} 1}$ and Weel. Biochem. Pharmacol. 2004, 67, 717-726.

12. Di Virgilio, A.L.; Iwami, K.; Wätjjen, W.; Kahl, R.; Gegen, G.H. Genotoxicity of the isoflavones genistein, daidzein and equol in V79 cells. Toxicol. Lett. 2004, 151, 151-162.

13. Oki, T.; Sowa, Y.; Hirose, T.; Takagaki, N.; Horinaka, M.; Nakanishi, R.; Yasuda, C.; Yoshida, T.; Kanazawa, M.; Satomi, Y.; Nishino, H.; Miki, T.; Sakai, T. Genistein induces Gadd45 gene and G2/M cell cycle arrest in the DU145 human prostate cancer cell line. FEBS Lett. 2004, 577, 55-59.

14. Kao, T.H.; Chen, B.H. Functional components in soybean cake and their effects on antioxidant activity. J. Agric. Food Chem. 2006, 54, 7544-7555.

15. Hewitt, A.L.; Singletary, K.W. Soy extract inhibits mammary adenocarcinoma growth in a syngeneic mouse model. Cancer Lett. 2003, 192, 133-143.

16. Constantinou, A.I.; Mehta, R.G.; Vaughan, A. Inhibition of N-methyl-N-nitrosourea-induced mammary tumors in rats by the soybean isoflavones. Anticancer Res. 1996, 16, 3293-3298.

17. Sakamoto, K. Synergistic effects of thearubigin and genistein on human prostate tumor cell (PC3) growth via cell cycle arrest. Cancer Lett. 2000, 151, 103-109.

18. Wei, H.; Wei, L.; Frenkel, K.; Bowen, R.; Barnes, S. Inhibition of tumor promoter-induced hydrogen peroxide formation in vitro and in vivo by genistein. Nutr. Cancer 1993, 20, 1-12.

19. Wei, H.; Bower, R.; Zhang, X.; Lebwohl, M. Isoflavone genistein inhibits the initiation and promotion of two-stage skin carcinogenesis in mice. Carcinogenesis 1998, 19, 1509-1514.

20. van Rossen, M.E.; Sluiter, W.; Bonthuis, F.; Jeekel, H.; Marquet, R.L.; van Eijck, C.H. Scavenging of reactive oxygen species leads to diminished peritoneal tumor recurrence. Cancer Res. 2000, 60, 5625-5629.

21. Bostwick, D.G.; Alexander, E.E.; Singh, R.; Shan A.; Qian J.; Santella, R.M.; Oberley, L.W.; Yan, T.; Zhong, W.; Jiang, X.; Oberley, T.D. Antioxidant enzyme expression and reactive oxygen species damage in prostatic intraepithelial neoplasia and cancer. Cancer 2000, 89, 123-134.

22. Dudek, E.J.; Shang, F.; Taylor, A. $\mathrm{H}_{2} \mathrm{O}_{2}$-mediated oxidative stress activates NF-kappaB in lens epithelial cells. Free Radic. Biol. Med. 2001, 31, 651-658.

23. Popiolkiewicz, J.; Polkowski, K.; Skierski, S.; Mazurek, A.P. In vitro toxicity evaluation in the development of new anticancer drugs-genistein glycosides. Cancer Lett. 2005, 229, 67-75.

24. Papazisis, K.T.; Zambouli, D.; Kimoundri, O.T.; Papadakis, E.S.; Vala, V.; Deromichalos, D.; Voyatzi, S.; Markala, D.; Destouni, E.; Boutis, L.; Kortsaris, A.H. Protein tyrosine kinase inhibitor, genistein, enhances apoptosis and cell cycle arrest in K562 cells treated with $\gamma$ irradiation. Cancer Lett. 2000, 160, 107-113.

25. Casagrande, F.; Darbon, J.M. p $21^{\mathrm{CIP} 1}$ is dispensable for the $\mathrm{G} 2$ arrest caused by genistein in human melanoma cells. Exp. Cell Res. 2000, 258, 101-108. 
26. Ying, C.; Hsu, J.T.; Hung, H.C.; Lin, D.H.; Chen, L.F.O.; Wang, L.K. Growth and cell cycle regulation by isoflavones in human breast carcinoma cells. Reprod. Nutr. Dev. 2002, 42, 55-64.

27. Ismail, I.A.; Kang, K.S.; Kim, J.W.; Sohn, Y.K. Genistein induces G2/M cell cycle arrest and apoptosis in rat neuroblastoma B35 cells; involvement of $\mathrm{p} 21^{\text {waf1/cip1 }}$, Bax and Bcl-2. Korea $J$. Pathol. 2006, 40, 39-347.

28. Katdare, M.; Osborne, M.; Telang, N.T. Soy isoflavone genistein modulates cell cycle progression and induces apoptosis in HER-2/neu oncogene expressing human breast epithelial cells. Int. J. Oncol. 2002, 21, 809-815.

29. Sarkar, F.H.; Li, Y. Mechanisms of cancer chemoprevention by soy isoflavone genistein. Cancer Metastasis Rev. 2002, 21, 265-280.

30. Li, Y.; Bhuiyan, M.; Alhasan, S.; Senderowicz, A.M.; Sarkar, F.H. Induction of apoptosis and inhibition of c-erbB-2 in breast cancer cells by flavopiridol. Clin. Cancer Res. 2000, 6, 223-229.

31. Su, S.J.; Yeh, T.M.; Chuang, W.J.; Ho, C.L.; Chang, K.L.; Cheng, H.L.; Liu, H.S.; Cheng, H.L.; Hsu, P.Y.; Chow, N.H. The novel targets for anti-angiogenesis of genistein on human cancer cells. Biochem. Pharmacol. 2005, 69, 307-318.

32. Conklin, C.M.J.; Bechberger, J.F.; MacFabe, D.; Guthrie, N.; Kurowska, E.M.; Naus, C.C. Genistein and quercetin increase connexin 43 and suppress growth of breast cancer cells. Carcinogenesis 2007, 28, 93-100.

33. Kim, H.Y.; Yu, R.; Kim, J.S.; Kim, Y.K.; Sung, M.K. Antiproliferative crude soy saponin extract modulates the expression of $\mathrm{I} \kappa \mathrm{B} \alpha$, protein kinase $\mathrm{C}$, and cyclooxygenase- 2 in human colon cancer cells. Cancer Lett. 2004, 210, 1-6.

34. Ellington, A.A.; Berhow, M.; Singletary, K.W. Induction of macroautophagy in human colon cancer cells by soybean B-group triterpenoid saponins. Carcinogenesis 2005, 26, 159-167.

35. Ellington, A.A.; Berhow, M.; Singletary, K.W. Inhibitionof Akt signaling and enhanced ERK1/2 activity are involved in induction of marcoautophagy by triterpenoid B-group soyasaponins in colon cancer cells. Carcinogenesis 2006, 27, 298-306.

36. Dalais, F.S.D.; Meliala, A.; Wattanapenpaiboon, N.; Frydenberg, M.; Siter, D.A.I.S; Thomson, W.K.; Wahlqvist, M.L. Effects of a diet rich in phytoestrogens on prostate-specific antigen and sex hormones in men diagnosed with prostate cancer. Urology. 2004, 64, 510-515.

37. Stephens, F.O. Phytoestrogens and prostate cancer: possible preventive role. Med. J. Aust. 1997, 167, 138-140.

38. Galati, G.; O’Brien, P.J. Potential toxicity of flavonoids and other dietary phenolics: significance for their chemopreventive and anticancer properties. Free Radic. Biol. Med. 2004, 37, 287-303.

39. McClain R.M.; Wolz, E.; Davidovich, A.; Bausch, J. Genetic toxicity studies with genistein. Food Chem. Toxicol. 2006, 44, 42-55.

40. McClain R.M.; Wolz, E.; Davidovich, A.; Edwards, J.; Bausch, J. Reproductive safety studies with genistein in rats. Food Chem. Toxicol. 2007, 45, 1319-1332.

41. Kao, T.H.; Lu, Y.F.; Chen, B.H. Preparative chromatography of four groups of isoflavones from soybean cake. Eur. Food Res. Technol. 2005, 221, 459-465.

42. Hsieh, H.C.; Kao, T.H.; Chen, B.H. A fast HPLC method for analysis of isoflavones in soybean. J. Liquid Chrom. Rel. Technol. 2004, 27, 315-324. 
43. SAS. SAS Procedures and SAS/Graph User's Guide, version 6, Software Release 8.2 (TS2MO) of the SAS System for Microsoft Windows; SAS Institute, Inc.: Cary, NC, 2004.

(C) 2007 by MDPI (http://www.mdpi.org). Reproduction is permitted for noncommercial purposes. 